\title{
Serine/Threonine-Protein Kinase 3
}

National Cancer Institute

\section{Source}

National Cancer Institute. Serine/Threonine-Protein Kinase 3. NCI Thesaurus. Code C99479.

Serine/threonine-protein kinase 3 (491 aa, $\sim 56 \mathrm{kDa}$ ) is encoded by the human ST K3 gene.

This protein plays a role in the mediation of both protein phosphorylation and signaling. 